PDFlib PLOP: PDF Linearization, Optimization, Protection

Page inserted by evaluation version www.pdflib.com - sales@pdflib.com 


\title{
A Sex Equality Approach to Sexual Assault
}

\author{
CATHARINE A. MACKINNON ${ }^{a}$ \\ University of Michigan Law School, Ann Arbor, Michigan 48109, USA
}

\begin{abstract}
Sexual assault is a practice of sex inequality. It is not generally addressed as such by law, including criminal law, and should be.
\end{abstract}

KEYWORDS: sexual assault; rape; sex; gender; sexuality; power; consent; hierarchy; inequality; equality; forced sex; criminal law; male dominance

Sexual assault is a sex-based violation. This analysis is supported by the data and experience on sexual assault that have emerged since $1970 .{ }^{1}$ Among humans, sexual abuse is systematically inflicted by and on people who are socially gendered unequal to one another. The gendered inferiority attributed to sexual victims, and used to target them, and the gendered superiority attached to sexual prowess, along with the erotization of subordination and dominance, are socially imbricated with established and inculcated notions and roles of masculinity and femininity respectively. A prominent observable regularity is that men more often perpetrate, women are more often victimized. Even more of the variance is explained by the observation that sexual atrocities are inflicted on those who have less social power by those who have more, among whom gender is the most significant cleavage of stratification.

In light of the evidence, human sexual aggression is best understood as socialattitudinal and ideological, role-bound and identity-defined-not natural. Causally speaking, nothing makes inevitable its high prevalence and incidence in everyday life, ${ }^{2}$ or in wars or genocides, except social-rank orderings, advantage-seeking, inculcation, imitation, and conformity (to peer behavior and pressure, standards of prior generations, orders, media representations, and the like). These forces plainly make sexually aggressive behavior attractive and possible by some people against certain others, producing social incentives for perpetrators to attack and pressures for victims to be ignored under many different conditions. ${ }^{3}$ Sexual perpetrators and victims are largely socially constructed males and females, respectively-gendered in part by societies that impel and excuse both their relative hierarchical positions and the violative acts that express and define those positions by attributing both to men's and women's natures or physical bodies.

Address for correspondence: Catharine MacKinnon, University of Michigan Law School, 625 South State Street, Ann Arbor, MI 48109-1215.

smrenier@umich.edu

${ }^{a}$ Elizabeth A. Long Professor of Law, University of Michigan, and long-term visitor, University of Chicago School of Law.

Ann. N.Y. Acad. Sci. 989: 265-275 (2003). (C) 2003 New York Academy of Sciences. 
In this light, as explanation for sexual aggression, appeals to biology are revealed to prove both too little and too much. In the first place, not all women are victims and not all men are aggressors, and not only women are victims and not only men are aggressors. That sexual assault is propelled, indeed motivated, by social hierarchy rather than factors or forces of nature is evidenced by the fact of biologically female sexual aggressors ${ }^{4}$ (if few, showing how powerful socialization is), as well as by the many biologically male victims and the child victims of both sexes, ${ }^{5}$ not to mention postmenopausal women victims and same-sex victims of both sexes, ${ }^{6}$ against all of whom sexual assault is a reproductive and, one suspects, evolutionary dead end.

Further evidence for a social over a biological explanation is the numbers of men who do not sexually aggress who have nothing wrong with them physically and the participation of race and class hierarchy in designating "appropriate" victims of sexual assault. ${ }^{7}$ In genocides, in which women of the group to be destroyed are systematically raped by men of the group intending to destroy them, nothing biological has changed from a prior nongenocidal era. What has changed is that a political decision is made to destroy another racial or ethnic or religious group and the realization that rape is a highly effective tool to that end. ${ }^{8}$ Nor do wars change men's biology; they do change the conditions of access, permission, and motivation for raping both women and men. In other words, sexual assault is based on social and political inequality not on biological distinction.

Embodied in the ideology of the naturalness of sexual assault (whether it takes the form of religious fundamentalism, fascism, or sociobiology) is necessarily the view that gender hierarchy - male supremacy and female inferiority — of which sexual aggression is a cardinal manifestation, is also natural. If the sexes are biologically different but not biologically superior and subordinate, sexual aggression is socially not biologically impelled, an act not of difference but of dominance, not of sexual dimorphism but of gender hierarchy. Put another way, because women are not men's sexual inferiors in nature, but are so ranked in societies in which sexual abuse of women in particular flourishes with social support, enforcing and expressing that inferiority, and because the sex roles and stereotypes that become realities gender sexual assault unequally and indelibly, and because gender is the social form sex takes, sexual abuse is properly analyzed as an act of sex inequality.

This realization is increasingly reflected by diverse legal authorities. The Supreme Court of Canada recognized in a 1993 rape case that "Sexual assault is in the vast majority of cases gender based. It ... constitutes a denial of any concept of equality for women." International authorities including the General Assembly of the United Nations, the Committee on the Elimination of All Forms of Discrimination Against Women, the Organization of American States, the Beijing Conference, and the Council of Europe have all defined and condemned sexual violence as a genderbased function of unequal social power between the sexes. ${ }^{10}$ The law against sexual harassment in the United States, which makes sexual incursions in employment and education civilly actionable as sex discrimination, construes sexual assault in certain settings as gender-based inequality. ${ }^{11}$ The U.S. Supreme Court once found that women are raped because they are women, calling the capacity to be raped a result of the victim's "very womanhood." 12 In the Violence Against Women Act (VAWA), rape was made civilly actionable as sex discrimination when the violence was "because of" or "on the basis of gender," including "animus based on the victim's gen- 
der." ${ }^{13}$ Presumably, Congress was not making a natural fact into a federal case, nor standing against nature when it legislated the United States' first zero tolerance standard for sex-based violence. Even the Supreme Court that invalidated the VAWA on other grounds did not question the legislative conclusion that sexual assault is generally describable as a practice of discrimination on the basis of sex. ${ }^{14}$

The growing consciousness of this reality is reflected virtually not at all in the criminal law of rape in the United States. Although sexual assault is always sexual and often physically violent, the awareness that rape is not so much an act of violence or sex as it is an act of sex inequality-specifically of sex eroticized by the dominance that inequality embodies and permits, of which physical violence is only one expression - is barely traceable in U.S. criminal law. Remarkably, given that criminal statutes are mostly state law, the equalization of which the Fourteenth Amendment was passed to guarantee, the well-documented sex inequalities in the criminal law of rape, from its design to most aspects of its state administration, ${ }^{15}$ have remained almost entirely free of Equal Protection scrutiny, except for those rare rape statutes that differentiate between men and women on their face. ${ }^{16}$ Surely the legal tolerance of sexual assault ${ }^{17}$ is not a fact of nature. It is a fact of sex inequality in human societies, supported by ideologies that explain and exonerate systemic abuses of women by appeals to biological fiat. And, if the U.S. criminal law of rape does not meet a sex equality standard, as contended here, it must also be said that it has not been legally subjected to one.

In fundamental aspects of its doctrine, the U.S. rape laws can be seen to presuppose and enforce inequality between women and men in sex. A central instance is the legal standard for consent to sex, which does not hold contested sexual interactions to a standard of sexual equality. That is, when the law of rape finds consent to sex, it does not look to see whether the parties were social equals in any sense, nor does it require mutuality or positive choice in sex, ${ }^{18}$ far less simultaneity of desire. The doctrine of consent in the law of forcible rape envisions instead unilateral initiation (the stereotyped acted/acted-upon model of male-dominant sex ${ }^{19}$ ) followed by accession or not by persons tacitly presumed equal. Consent is usually proven by the acted-upon not saying no; it can, however, even famously include saying no. ${ }^{20}$

A lot of not-yes-saying passes for consent to sex. ${ }^{21}$ The accession to proceeding known as legal consent that makes sex not rape can, in addition to an express no that becomes a legal yes, include resigned, silent, passive, dissociated acquiescence in acts one despairs at stopping; fraud or pretense producing compliance in intercourse for false reasons ${ }^{22}$ or with persons who are not who they say they are; multiplicity triggered by terror or programming (so that the person who accedes to the sex is just one inhabitant of the body with whom sex is had) ${ }^{23}$; and fear of abuse short of death or maiming or severe bodily injury (such as loss of one's job or not being able to graduate from high school, and including jurisdictions that do not consider rape itself a form of severe bodily injury) resulting in letting sex happen. ${ }^{24}$

Outside settings of war and genocide, little to no legal attention is paid to whether the parties enter sexual intercourse as social equals. Not even known hierarchies of boss-worker, teacher-student, doctor-patient, priest-penitent, or lawyer-client formally register in the doctrine of the criminal law of rape. This law is indifferent to whether the sexual transactions in which assault is claimed occurred at (what contract law calls) arm's length. People who could not sign a binding contract, under conditions of overreaching under which it would not be enforced, can have sex and 
the law is none the wiser. In popular culture, where no one (man or women) describes a magical moment of sexual intimacy or connection or eroticism as "consensual," the term consent is nonetheless used as if it actually means choice, mutuality, and desire. This is a fiction. Within its legal ambit, consent can include sex that is wanted, but it can also include sex that is not at all wanted and is forced by inequality.

Usually, consent is a club used as a defense by a man at the point a woman says he raped her, or, in what amounts to the same thing, when she says that her prostitution was not freely chosen. Consent is more attributed than exercised. As is by now well known, if sexual intercourse took place, particularly if the woman had had sex before, if the parties knew each other, or lived together, or if the man paid, consent tends to be presumed or found. ${ }^{25}$ Whether receipt of money makes sex wanted, or knowing a man or living in the same household with him means one wants to have sex with him, is not asked because whether a person wants to have sex is not the full legal meaning of consent. Whether she or he tolerated it, or could have appeared to the defendant to have gone along with it, is included.

This is to say one simple thing: consent to sex is not the same as wanting it. That a woman has reasons for giving up and letting sex happen that have nothing whatever to do with desire to have sex and everything to do with social gender hierarchy - all the way from saving one's job or future to placating a physically or emotionally abusive man - is irrelevant to the criminal law. No doubt many people think it should be. It fails to meet an equality standard, however. An equality standard, such as the one applied in the civil law that recognizes sexual harassment is sex discrimination, requires that sex be welcome. ${ }^{26}$ For the criminal law to change to this standard would require that sex be wanted for it not to be assaultive.

Awareness of social hierarchy is absent in the criminal law of rape's treatment of force as well. In this area of law, forms of force typically correlated with male sex and gender-such as the economic dominion of employers, dominance in the patriarchal family, authority of teachers and religious leaders, state office of police officers and prison guards, and the credibility any man has (some much more than others based on race and class and age), not to mention the clout of male approval and the masculine ability to affirm and confirm feminine identity - are not regarded as forms of force at all. But they are. Whether or not men occupy these roles, these forms of power are socially male in that they are not equally available for women to assert over men, socially speaking, because women in general are neither socialized to these forms of power nor, as women, are they commonly authorized, entitled, socially positioned, or permitted to exercise them. That there are exceptions confirms the rule as well as further highlights its social determinants.

Of all the forms that power can take, the criminal law of rape's doctrine of force similarly registers only physical overpowering. ${ }^{27}$ Some courts have begun to consider that a variety of factors can constitute force, such as Pennsylvania's embodiment of "moral, psychological or intellectual force used to compel a person to engage in sexual intercourse against that person's will" in its definition of "forcible compulsion." It also includes "the extent to which the accused may have been in a position of authority, domination or custodial control over the victim," together with age, mental and physical conditions, and the atmosphere and physical setting. ${ }^{28}$ What even this standard, which is not the norm, does not expressly include is attention to inequalities including sex and race (as is well known, racism targets women of spe- 
cific racial groups for sexual incursions and in the United States often accords greater credibility to white people than to African-Americans), and other major social inequalities. Even consideration of physical force under standard approaches typically shows little sensitivity to the physical factors of height and weight, which on average stack the deck in favor of men over women. ${ }^{29}$

Only extreme physical force, preferably including weapons not the penis, is usually credible enough to meet the criminal law's standard for enough force for sex to look like rape. Depending on how well the parties know each other, the amount and type of force required to prove that the sex was physically forced escalates. ${ }^{30}$ While resistance requirements have been largely modified or abolished, it is as if they have not, if a woman's calculation not to fight because she would rather be raped than dead, for example, an assessment some women make every day, means that the sexual acts are legally determined not to have been forced.

Typically, the only vulnerability recognized by the rape law as tantamount to an inequality is age, ${ }^{31}$ in most places for underage girls only (in some for boys as well). The law of statutory rape makes all sex rape below an age line. While simplifying the administration of justice, this rule (along with a similar result of strict prohibitions on sex between teachers and students) confuses people by defining as rape some sex that some people want to have. It also presumptively authorizes all sex above the age line whether it was wanted or not, unless proven nonconsensual by standards that take no inequalities into account. Other inequalities, such as disparities of access and trust, that often go with age but do not end with the age of majority, are also neglected above and below the line.

If the rape law worked, there would be no need for statutory rape laws. Abuse of power, access, trust, and exploitation of vulnerabilities to pressure people into sex that is not wanted for its own sake would be illegal. Age would be one powerful inequality to be taken into account. Instead, the only inequality the law will countenance is youth, whether statutory rape laws are justified as making consent irrelevant or force unnecessary or both (the law is oddly indifferent to its actual rationale). Young age or age differential below a certain age is thus ossified into an absolute rule. This segregates some of the most sympathetic cases for relative structural powerlessness in sexual interactions and leaves the rest of the victims-including, in most states, underage boys who have sex with women over the age of majority-unprotected, their inequalities uncounted. By cushioning its excesses, this helps keep male dominance as a social system in place. One also suspects that debates over shifting the age of consent are driven more by what legislators (mainly men) want in a female sex object than by what sex women want in their lives and when they want it.

Sex is relational; so is sexual assault. In unequal societies, what makes sexual assault sexual as well as possible is the hierarchy of relation between the parties. Rape is thus a crime of sexualized dominance on the basis of sex (which often includes sex and age, sex and race, sex and class variously combined and pyramided) that is legally unrecognized as such. Inequality, its central dynamic, is flat-out ignored by the criminal law. Far from promoting equality between women and men, the criminal law tacitly assumes that such equality already exists. More accurately still, it shows total lack of interest in whether it exists or not. ${ }^{32}$ In other words, exactly what this crime is, the law has refused to make criminal about it. This misfit between the law's concept of sexual assault and its reality produces legal standards that cannot see 
abuse in the real world and encourages neglect or worse by legal actors of the dynamics that make the abuse happen. This in turn serves as state collaboration in sexual assault and accordingly in the inequality of the sexes.

In this view, until inequality is directly addressed by the law of sexual assault, nothing adequate will be done about it. You cannot solve a problem you do not name. For the same reason, legal reform through consent alone or force alone, while improvements, will intrinsically fall short unless the concepts are fundamentally recast in terms of inequality. Requiring affirmative consent, as some states do, ${ }^{33}$ for example, is an improvement over existing law, but can be polluted by inequality. No means no is an improvement over no meaning yes, but until equality exists, not even yes can reliably mean yes. Yes can be coerced. It can be the outcome of forced choices, precluded options, constrained alternatives, as well as adaptive preferences conditioned by inequalities. This may be why states that require affirmative consent also require that it be freely chosen. But whether the experiences of inequalities that make choice unfree - say, for instance, having been sexually abused in childhood, as are a third to a half of girls in the United States, ${ }^{34}$ not to mention first sexual intercourse being forced, as it is documented to be for up to a third of all girls in the world $^{35}$ - are adequately included in the evaluations of the facts of individual cases remains to be seen.

The problem with consent-only approaches to criminal law reform is that sex under conditions of inequality can look consensual when it is not wanted, at times because women know that sex that women want is the sex men want from women. Men in positions of power over women can thus secure sex that looks, even is, consensual without that sex ever being freely chosen, far less desired. Consent, in other words, has never legally been equivalent to free choice. Even if it did in law, if the conditions for the exercise of freedom in life are not ensured-meaning actual conditions of equality, or a standard sensitive to inequalities between the parties so long as conditions of inequality exist - an autonomy approach to consent will not alone solve this problem in real life. Autonomy in sex cannot exist without sex equality. Similarly, force-alone approaches cannot address the problem of sexual assault in real life unless forms of force other than the physical, including all of those that enforce inequalities, are expressly recognized.

The question therefore framed is: what would a rape law look like that understood sexual assault as a practice of inequality? In brief, it would recognize that rape is a physical attack of a sexual nature under coercive conditions, ${ }^{36}$ and that inequalities are coercive conditions. The law of sexual assault could make it a crime to take advantage of a relation of inequality (including access or trust) to force sex on a person who does not want it. If force were defined to include inequalities of power, meaning social hierarchies, and consent were replaced with a welcomeness standard, the law of rape would begin to approximate the reality of forced and unwanted sex. Force could be defined so that it is sensitive to the vulnerabilities social hierarchies concretely create: age (middle over young and old), family (husband over wife, parents over children, older children over younger children), race (in the United States, white over people of color), authority (educational, medical, legal, spiritual among them); law (police and prison guards over citizens and inmates), as well as illegal statuses such as those created by the law of immigration, homosexuality, and prostitution; and economics (poverty, and employers over employees). 
Gender too is a social hierarchy (masculine over feminine), ringed with stereotype, enforced by socialization to subordinate and superordinate identification as well as by physical force. Socially, it is largely fused with sex (male and female). The idea here is not to prohibit sexual contact between hierarchical unequals per se, but to legally interpret sex that a hierarchical subordinate says was unwanted in light of the forms of force that animate the hierarchy between the parties. To counter a claim that sex was forced by inequality, a defendant could (among other defenses) prove the sex was wanted - affirmatively and freely wanted-despite the inequality, and was not forced by the socially entrenched forms of power that distinguish the parties. ${ }^{37}$ The assumption that money provides or shows consent to sex would be replaced by the assumption that money is a form of force in sex. On a social level, inequalities could also be reduced, of course. A recognition in law that sex is made an inequality in society through gender hierarchy, and sexual assault is a central practice and expression of that inequality, would go a long way toward ending its considerable social and legal impunity and toward making sexual assault obsolete.

If society is structured to promote, and even encourage, sexual assault, and the law against it evades the forces driving it so that there is nothing effective to stop it, no wonder sexual assault happens. An approach designed to rectify this situation could underlie new statutes, provide a set of common law rules for interpreting existing statutes, or sketch a set of equality standards for assessing the Fourteenth Amendment constitutionality of existing state practices or conformity of national laws and practices with international obligations. As a priority, new civil rights laws - sex equality laws - could be passed for all victims of sexual assault to use. Civil laws potentially offer accountability to survivors, a forum with dignity and control by them, the stigma of bigotry for perpetrators, a possibility of reparations, and the potential for social transformation by empowering survivors. This is not to say that perpetrators do not deserve incarceration, but rather to say that jail has not tended to change their behavior, and indeed has often entrenched and escalated it. Civil rights laws offer the prospect of redistributing power, altering the inequalities that give rise to the abuse.

This framework for analysis has been described as principles of direction in order to be adaptable to diverse cultural settings and varying structures of existing law. Should anyone act on it, the approach offers the chance to embody in law the sexual equality that people often say they want in their laws and in their relationships.

\section{ACKNOWLEDGMENTS}

The thoughts and research help of Lisa Cardyn and Candice Aloisi are gratefully acknowledged.

\section{NOTES AND REFERENCES}

1. Data are summarized in Catharine A. MacKinnon, Sex Equality [hereinafter, Sex Equality] 776-778 (Foundation Press, 2001).

2. See Mary P. Koss et al., No Safe Haven: Male Violence Against Women at Home, at Work, and in the Community 167-71 (1994) (analyzing major studies on rape prevalence done as of 1994, many showing approximately 20 percent of women subject to 
completed rape, some numbers lower, some higher); Diana E.H. Russell, Sexual Exploitation: Rape, Child Sexual Abuse, and Workplace Harassment 31, 35 (1984) (finding 9.5 percent of rapes reported and 24 percent of women experiencing rape in lifetime in large probability sample).

3. The work of Diana E.H. Russell, David Finkelhor, Peggy Reeves Sanday, Diana Scully, and many others converges on this conclusion.

4. Andrea J. Sedlak \& Diane D. Broadhurst, U.S. Department of Health \& Human Services, Executive Summary of the Third National Incidence Study of Child Abuse and Neglect 14 (1996) found that 12 percent of all sexually abused children are abused by a female.

5. Before they reach the age of majority, 38 percent of girls report having been sexually abused, most by men close to them or in authority over them. The average age of first abuse is around ten. Diana E.H. Russell, "The Incidence and Prevalence of Intrafamilial and Extrafamilial Sexual Abuse of Female Children," in Handbook on Sexual Abuse of Children 19, 24 (Lenore E. Walker ed., 1986); Diana E.H. Russell, The Secret Trauma 99-100 (1986); Gail E. Wyatt, "The Sexual Abuse of Afro-American and White American Women in Childhood," 9 Child Abuse \& Neglect 507 (1985) (finding 57 percent of sample of African American women and 67 percent of white American women report at least one incident of sexual abuse before age eighteen).

6. Data on sexually assaulted men includes documentation showing that 6 percent of the rapes reported to a survey of victims age 12 and over in 1996 were rapes of men by men. See Bureau of Justice Statistics, 2001 National Crime Victimization Survey, Bureau of Justice Statistics Bulletin Tbl 2, Tbl 38 (2001). Sexual abuse of boys has been found to be "common, underreported, underrecognized, and undertreated." William C. Holmes \& Gail B. Slap, "Sexual Abuse of Boys: Definition, Prevalence, Correlates, Sequelae, and Management," 280 JAMA 1855, 1855 (1998).

7. African American women are generally considered to be subjected to a higher incidence of rape than white women in the American population. See Diana E.H. Russell, Sexual Exploitation 82 (1984) (reporting all studies to date). Professor Russell's study found that the highest percentage of women to be subjected to at least one rape or attempted rape were Native American women ( 55 percent), followed by Jewish women (50 percent), white non-Jewish women (45 percent), African American women (44 percent), Latinas (30 percent), Asian women (17 percent), Filipinas (17 percent), and other ethnicities ( 28 percent). See id. at 83-84. Note that these are figures for women ever raped or victimzed by attempted rape, not the number of rapes. According to recent statistics, persons from households with low incomes experienced higher violent crime victimization rates than persons from wealthier households. For instance, persons from households with annual incomes below $\$ 7,500$ were 26 times as likely as those from households with incomes of $\$ 75,000$ to be rape and sexual assault victims, and have significantly higher rates of rape, sexual assault, and aggravated assault compared with persons in all other income groups. See Bureau of Justice Statistics, Criminal Victimization in the United States 2000, Table $14(2000)$.

8. See, for example, Binaifer Nowrojee, Shattered Lives: Sexual Violence During the Rwandan_Genocide and its Aftermath 1-2 (1996)

9. R. v. Osolin [1993] 4 S.C.R. 595, 669 (Cory, J.).

10. The General Assembly of the United Nations in 1994 adopted a resolution condemning sexual violence that defined it as gender-based violence, G.A. Res. 48/104, U.N GAOR, 48th Sess., at art. 4, U.N. Doc. A/48/49 (1994); 33 I.L.M. 1049. General Recommendation No. 19, Committee on the Elimination of Discrimination Against Women, 11th Sess., U.N. Doc. CEDAW/C/1992/L.1/Add. 15 (1992). The most farreaching international convention to date, the Convention of Belem do Para adopted by the Organization of American States in 1994, recognized in its preamble that violence against women "is ... a manifestation of the historically unequal power relations between women and men." Convention of Belem do Para, 33 I.L.M. 1994. It declares that "every woman has the right to be free from violence in both the public and private spheres" Id. at art. 3, and required in detail that states parties and societies take action "to protect the right of every woman to be free from violence." Id. at 
art. 10. The Beijing Declaration and Platform of Action in 1995 expressly embraced the right of women "to have control over and decide freely and responsibly on matters related to their sexuality" as a human right, Beijing Declaration and Platform for Action of the United Nations Fourth World Conference on Women, U.N. Doc. A/ CONF.177/20 (1995) at 96, and condemned violence against women as "a manifestation of the historically unequal power relations between men and women, which have led to domination over and discrimination against women by men," all expressly analyzed as social realities. Id. at $\$ 118$. The Committee of Ministers of the Council of Europe recently "reaffirm[ed] that violence towards women is the result of an imbalance of power between men and women and is leading to serious discrimination against the female sex, both within society and within the family." Council of Europe, Committee of Ministers, Recommendation Rec(2002)5 of the Committee of Ministers to member states on the protection of women against violence (30 April 2002).

11. See Meritor Sav. Bank v. Vinson, 477 U.S. 57 (1986) (recognizing hostile environment sexual harassment on facts of repeated rape as sex discrimination in employment); Alexander v. Yale University, 631 F.2d 178 (2d Cir. 1980) (recognizing sexual harassment in education as prohibited under Title IX prohibition on sex discrimination); Franklin v. Gwinnet County Public Schools, 503 U.S. 50 (1992) (permitting damages for Title IX sexual harassment).

12. Dothard v. Rawlinson, 433 U.S. 321, 336 (1977) (permitting women to be excluded from contact positions in high security prison employment on the basis of sex because of capacity to be raped). The Court may have been thinking of sexual biology, but the sexed reality was nonetheless observed.

13. 42 U.S.C. $§ 13981$ (1994).

14. See United States v. Morrison, 529 U.S. 598, 635-36 (2000).

15. Most sexual assaults remain unreported, unprosecuted, and unremedied. See, for example, National Victim Center, Crime Victims Research and Treatment Center, Rape in America 5 (1992) (finding that 16 percent of rapes are reported); Staff of Senate Comm. on the Judiciary, 103rd Cong., The Response to Rape: Detours on the Road to Equal Justice iii (Comm. Print 1993) (drawing on data from several jurisdictions, concluding that 98 percent of rape victims "never see their attacker caught, tried and imprisoned.")

16. An example is Michael M. v. Superior Court of Sonoma County, 450 U.S. 464 (1981).

17. The manifest ineffectiveness of existing laws against sexual assault was amply demonstrated before the Congress that passed the Violence Against Women Act. See Women and Violence: Hearings Before the Senate Comm. on the Judiciary, 101 Cong. (1990). Estimates are that the likelihood of a rape complaint ending in conviction is 2 to 5 percent of rapes. See Joan McGregor, "Introduction to Symposium on Philosophical Issues in Rape Law," 11 Law \& Phil. 1, 2 (1992).

18. The Antioch College Sexual Offense Prevention Policy (June 8, 1996), reproduced in Sex Equality 836-837, does.

19. The model was recently pungently described by a female-to-male transsexed person and long-time advocate of S/M (sadism and masochism) in sex, when asked why he transsexed: "[r]unning the fuck is an integral part of maleness in our society." Patrick Califia, Transman Seeks Sex Life: T 4 U, Village Voice, June 26-July 2, 2002

20. See, e.g., Commonwealth v. Berkowitz, 609 A.2d 1338 (Pa. Super. Ct.), aff'd 641 A.2d 1161 (Pa. 1994). The Pennsylvania legislature attempted to address the problem after public outcry, see, e.g., $18 \mathrm{~Pa}$. Cons. Stat.. Ann. § 3124.1, but it is unclear if they did. One better approach can be seen in R. v. Ewanchuk, [1999] 169 D.L.R. 4th 193 (Can.) (holding that consent is a purely subjective fact to be determined by trial judge by ascertaining complainant's state of mind toward sexual touching when it occurred and that consent out of fear is not freely given, hence ineffective).

21. Women are not alone in this. See, e.g., R. v. R.J.S. [1994] 123 Nfld \& P.E.I.R. 317 (finding that erection may be sufficient evidence of consent to sex).

22. Examples are Boro v. Superior Court, 163 Cal. App. 3d 1224, 210 Cal. Rptr. 122 (1985) and People v. Ogunmola, 238 Cal. Rptr. 300 (Cal. Ct. App. 2d Dist. 1987) involving doctors and patients. In Boro, the patient, who had permitted sex in the 
guise of treatment, was found to have consented. In Ogunmola, two patients who consented to an examination but were penetrated by the doctor's penis instead were found not to have consented. California partially addressed the Boro situation by statute prohibiting sexual intercourse "procured by false or fraudulent representation or pretense that is made with the intent to create fear, and which does induce fear" with a spousal exception. Cal. Penal Code $\$ 266 C$. (The spousal exceptional was removed by amendment in 1994, see Cal. Penal Code \$266C.) Recent developments in the law of rape by fraud are discussed in Patricia J. Falk, "Rape by Fraud and Rape by Coercion," 64 Brook. L. Rev. 39, 89-131 (1998). See also Jane E. Larson, "Women Understand So Little, They Call My Good Nature "Deceit": A Feminist Rethinking of Seduction, 93 Colum. L. Rev. 374 (1993).

23. For general discussion of multiplicity, see Daniel Brown, Alan W. Scheflin, \& D. Corydon Hammond et al., Memory, Trauma Treatment, and the Law (1998); for a brilliant treatment of the subject, see Harvey Schwartz, Dialogues with Forgotten Voices (2000). See also Carole Goettman, George B. Greaves \& Philip M. Coons, Multiple Personality and Dissociation, 1791-1992, A Complete Bibliography (1994) and Sabra Owens, Criminal Responsibility and Multiple Personality Defendant (American Bar Association, 1997).

24. See, for example, State v. Thompson, 792 P.2d 1103 (Mont. 1990) (defendant high school principal allegedly forced student to submit to sexual intercourse by threatening to prevent her from graduating from high school; court affirmed dismissal of sexual assault charges because of lack of physical force). The Supreme Court of Canada found a rape threat to be a threat of severe bodily harm in R. v. McCraw, [1991] 3 S.C.R. 72, a conclusion far from obvious to many courts in the world.

25. See Morrison Torrey, "When Will We Be Believed?", 24 U.C. Davis Law Review 1013; Robin West, "Equality Theory, Marital Rape, and the Promise of the Fourteenth Amendment," 42 Univ. Fla. L. Rev. 45, 66-70 (1990). See also Jaye Sitton, Comment, "Old Wine in New Bottles: The 'Marital' Rape Allowance," 72 N.C.L. Rev. 261, 280-281 (1993) (describing extension of traditional marital rape law's doctrine of implied consent to cohabitants and "voluntary social companions.")

26. For the standard's initial articulation, see Meritor Savings Bank v. Vinson, 477 U.S. 57, 69 (1986), a sexual harassment case distinguishing between the criminal law standard of "voluntary" sex and the civil equality standard of "unwelcome" sex. For further discussion, see Sex Equality 977-989.

27. An excellent examination of this topic is Stephen Schulhofer, Unwanted Sex: The Culture of Intimidation and the Failure of Law (Harvard University Press, 1998).

28. Commonwealth v. Rhodes, 510 A.2d 1217, 1226 (Pa. 1986).

29. See People v. Warren, 446 N.E.2d 591 (Ill. App. Ct. 1983) (finding of stranger rape allegations that $6^{\prime} 3^{\prime \prime} 185$-pound defendant, "apart from picking up [5'2" 100 -pound woman] complainant and carrying her into and out of the woods" where he had sex with her, insufficient force, and faulting complainant for failing to resist). Analysis of the role of women's and men's different average height and weight in the context of potential rape can be found in Dothard v. Rawlinson, 433 U.S. 321 (1977) (holding that a particular minimum height/weight standard for prison guards at male-only prisons discriminated against women on the basis of sex).

30. My impression of marital rape cases where they are prosecuted is that the amount of force required for a conviction is often extreme, compared with what is required in stranger rape cases in the same jurisdictions.

31. Some states have prohibitions similar to statutory rape for prison guards, e.g. Conn. Penal Code $\S 53 \mathrm{a}-71$.

32. One of the few legal discussions of this question took place in the Michael M. case, Michael M. v. Superior Court of Sonoma County, 450 U.S. 464 (1981), the Supreme Court justices, majority and dissenting alike, falling all over each other not to question whether women and men were equal in sex in the name of sexual egalitarianism.

33. See, for example, State in the Interest of M.T.S., 609 A.2d 1266 (N.J. 1992).

34. Before they reach the age of majority, 38 percent of girls report having been sexually abused, most by men close to them or in authority over them. See Diana E. H. Russell, "The Incidence and prevalence of intrafamilial and Extrafamilial Sexual Abuse 
of Female Children," in Handbook on Sexual Abuse of Children 19, 24 (Lenore E. Walker ed., 1998) (also finding 16 percent of girls abused by a family member); Diana E.H. Russell, The Secret Trauma 99-100 (1986).

35. World Health Organization, World Report on Violence and Health 149 (Etienne G. Krug et al., eds, Geneva 2002) (finding "up to one-third of adolescent girls report their first sexual experience as being forced.").

36. This is a variant on the test in Prosecutor v. Akayesu, Case No. ICTR 964 T (1998) addressing rape in the Rwandan genocide. There, the coercive conditions were provided by the other jurisdictional requisites under the Tribunal's statute, which include crimes against humanity and genocide. It is also enacted at Cal. Civ. Code 52.4 (c) (2) as a civil claim for gender-based discrimination.

37. This arrangement could make a reconstructed definition of consent into an affirmative defense. 